\title{
Clarifying the Definition of Religion Under English Law: The Need for a Universal Definition
}

\author{
RUSSELL SANDBERG ${ }^{1}$ \\ Head of Law and Reader in Law, Cardiff University
}

There is no universal definition of religion under English law. Instead, different definitions have been developed by courts and tribunals in relation to different religious rights. Although there have been moves towards the harmonisation of these different definitions, recent decisions have reversed that trend. This article explores for the first time how this has led to a confused and contradictory case law. It begins by surveying how religion has been defined in registration law, charity law, human rights law and discrimination law, the moves towards harmonisation and the counter-tendencies in the recent decisions. It places the recent decisions within their broader legal context and points out a number of contradictions and uncertainties. Arguing that a universal definition of religion under English law is now needed, it synthesises the case law to identify the elements of a universal definition that already exist. The article examines how these can be refashioned in order to remove inconsistencies that exist in different areas of law. Drawing upon insights from the sociology of religion, the article concludes by proposing a new definition.

Keywords: definition, religion, charity, registration, discrimination, human rights

\section{INTRODUCTION}

There has never been a universal legal definition of religion in English law, and experience across the common law world over many years has shown the pitfalls of attempting to attach a narrowly circumscribed meaning to the word. There are several reasons for this - the different contexts in which the issue may arise, the variety of world religions, developments of new religions and religious practices, and developments in the common understanding of the concept of religion due to cultural changes in society. ${ }^{2}$

A number of definitions exist in law in relation to religion and belief. ... They reflect, to some extent, the different purposes that the laws are intended to have.... What is, however, common with all those definitions

1 I am grateful to Dr Sharon Thompson, Caroline Roberts and Frank Cranmer for their helpful comments on a draft of this article.

$2 \quad R$ (on the Application of Hodkin) $v$ Registrar General of Births, Deaths and Marriages [2013] UKSC 77 para 34 per Lord Toulson. 
is that none seeks to define what actual faiths or beliefs are covered by the law. That is left to the courts to decide, which is proper.... The courts are best placed to make decisions on these difficult matters, taking into account all the information that they will have before them. ${ }^{3}$

Like all definitions, legal definitions primarily serve as mechanisms for inclusion and exclusion. ${ }^{4}$ Legal definitions demarcate the granting of benefits and burdens, of rights and duties: those included in the definition are recognised by law; those excluded are denied legal recognition..$^{5}$ Legal definitions of religion which are adopted, whether explicitly or implicitly, determine which individuals and groups should be bestowed with legal advantages by virtue of the fact that they are 'religious'. ${ }^{6}$ Defining religion is, therefore, 'an exercise of power' which can have serious repercussions. ' It is also something that sometimes cannot be avoided. Unlike scholars who are able to recognise the complexity of the issue, posit a range of partial definitions and then move on, legal actors may well find that determining the definition of religion is crucial to the claim that they are dealing with. ${ }^{8}$

The importance of defining religion is felt under English law despite the fact that there is no compulsory registration scheme for religious groups. ${ }^{9}$ Instead, a multitude of overlapping laws have been enacted to recognise religious groups and to enable them to benefit from legal and fiscal advantages, most notably in the form of exceptions from otherwise generally applicable obligations. Religious groups may register their buildings as places of public religious worship and for the solemnisation of marriage..$^{10}$ In addition, such groups may seek to register as a charity for the advancement of religion. ${ }^{11}$ Individuals enjoy the human right to freedom of thought, conscience and religion and protection from discrimination on grounds of religion or belief. ${ }^{12}$ The definition and understanding of religion differs for each of these different religious rights. This has led to the situation described by Lord Toulson and Baroness Scotland above: recognising the lack of a universal definition of religion and

3 Baroness Scotland, HL Deb, 13 July 2005, vol 684, cols 1107-1108.

$4 \quad$ R Sandberg, Religion, Law and Society (Cambridge, 2014), p 39.

5 See, eg, G Thornton, Legislative Drafting (third edition, Oxford, 1987), pp 56-57. See also V Crabbe, Legislative Drafting (London, 1993), p 109.

6 See J Beckford, 'The politics of defining religion in secular society' in J Platvoet and A Molendijk (eds) The Pragmatics of Defining Religion: Contexts, Concepts \& Contests (Leiden, 1999), pp 23-40.

7 A Aldridge, Religion in the Contemporary World: a sociological introduction (third edition, Oxford, 2013), p 22.

8 P Edge, 'Determining religion in English courts', (2012) 1:2 Oxford Journal of Law and Religion $402-423$.

9 This article focuses on the law in England and Wales. The legal and religious context in Scotland and Northern Ireland merits separate treatment.

10 Places of Worship Registration Act 1855; Marriage Act 1949, s 4.

11 Charities Act 2011.

12 European Convention on Human Rights, Article 9; Equality Act 2010, s 10. 
the practice whereby the matter is largely left to the courts to adjudicate. Richard Robinson distinguished between 'stipulative' (or specific) definitions that announce that the subject is to be understood in a certain sense in a certain context and 'lexical' (or universal) definitions that report the customary meaning of the word. ${ }^{13}$ Under English law, there are several stipulative or specific definitions of religion developed by the case law on each area of law. However, there is no lexical or universal definition of religion.

This article will contend that recent decisions have underscored the need for such a universal definition. The first part of this article will take a chronological approach, exploring how the definition of religion under English law has developed over the last fifty years. It will be shown that there have been some moves towards the convergence of the different definitions of religion. The second part will explore how recent decisions by the Supreme Court and the Charity Commission have reversed this trend. It will be argued that these decisions have resulted in a complex and conflicting case law which points to a renewed need for a universal definition of religion under English law. The third and final part will further this analysis, drawing upon insights from the sociology of religion to suggest how a universal definition of religion could develop.

\section{TOWARDS A UNIVERSAL DEFINITION OF RELIGION}

\section{The common law definition}

Originally, the issue of defining religion did not arise. Following the English Reformation of the 1530s, there was only one lawful religion, the established Church of England. ${ }^{14}$ A category of religion was therefore meaningless. When the Preamble to the Statute of Charitable Uses 1601 stated that gifts for the repair of churches were charitable, it was clear that this referred to the buildings of the established church. ${ }^{15}$ And when subsequent case law recognised that trusts, gifts and institutions for the 'advancement of religion' were charitable and thus entitled to legal and fiscal advantages, it was likewise understood

13 R Robinson, Definition (Oxford, 1954), p 19.

14 The English Reformation came later and was a different beast from that felt on the Continent. The divorce from Rome in the 1530 s under Henry VIII was not a religious upheaval that required political and constitutional reconstruction; rather it was a political and constitutional act that led in time to religious upheaval. See G Elton, 'The Reformation in England' in G Elton (ed), The New Cambridge Modern History Volume 2: the Reformation, 1520-1559 (second edition, Cambridge, 1990), pp 262-287; F Maitland, English Law and the Renaissance (Cambridge, 1901), p 9.

15 The Mortmain and Charitable Uses Act 1888 repealed the statute itself but expressly preserved the preamble. The Charities Act 1960 repealed the 1888 Act and thus the preamble. However, its final repeal does not affect the authority of the cases decided on it nor the principles on which future cases are to be decided: Incorporated Council of Law Reporting for England and Wales $v$ A-G [1971] Ch 626 at 644. See also Charities Act 2011 Schedule 7, Part 1. 
that this protected only the established Church of England. ${ }^{16}$ The 'superstitious use' - that is, a trust for false religious purposes - was void. ${ }^{17}$ As Newark put it, such gifts were 'against public policy as furthering the schisms of nonconformity, the errors of Rome or the infidelity of Judaism or heathenism'. ${ }^{18}$ The long and piecemeal process of religious toleration, whereby disabilities placed on other religions were gradually removed, widened considerably the concept of advancement of religion and also changed the rationale for protecting religion. ${ }^{19}$ Rather than furthering the mission of the established church and preventing heretical and false religions, it gradually became understood that the protection of religion provided recognition of the psychological and social worth of individual religiosity. ${ }^{20}$ As Lord Reid noted in Gilmour $v$ Coats, English law no longer prefers 'one religion to another' but 'assumes that it is good for man to have and to practise a religion'. ${ }^{21}$

It was not until the latter years of the twentieth century, however, that domestic courts elucidated a definition of religion, based upon stated criteria, and used this definition to determine claims. This occurred in two cases, concerning registration and charitable status respectively. In the first, $R v$ Registrar General, ex parte Segerdal, ${ }^{22}$ the Court of Appeal upheld the decision by the Registrar General not to register a chapel of the Church of Scientology as 'a place of meeting for religious worship' under section 3 of the Places of Worship Registration Act 1855 . For Buckley LJ and Winn LJ, the determinative factor was that there was no worship. Winn LJ held that the adherents did not 'humble themselves in reverence and recognition of the dominant power and control of any entity or being outside their own body and life'; ${ }^{23}$ while Buckley LJ held that worship 'must have some at least of the following characteristics: submission to the object worshipped, veneration of that object, praise, thanksgiving, prayer or intercession'. ${ }^{24}$ He found that the evidence put forward, including the Church of Scientology's book of ceremonies, contained 'no element of

Pember $v$ Inhabitants of Kington (1639) 1 EqCasAbr 95; Tot 34; Special Commissioners of Income Tax $v$ Pemsel [1891] AC 531.

17 P Edge, Legal Responses to Religious Difference (The Hague, 2002), p 5. However, such gifts were sometimes upheld. In Da Costa v De Praz (1754) 2 Swan 487n, a gift to advance the Jewish religion was held to be unlawful but Lord Hardwicke left it to the Crown to direct a $c y$-près application whereby the gift was applied but for the purposes of the Christian religion.

18 F Newark, 'Public benefit and religious trusts', (1946) 62 Law Quarterly Review 234-247 at 235.

19 See R Sandberg, Law and Religion (Cambridge, 2011), chapter 2.

20 F Quint and P Hodkin, 'The development of tolerance and diversity in the treatment of religion in charity law', (2007) 10:2 Charity Law and Practice Review 1-16 at 3.

21 [1949] AC 426 at 459.

$22[1970] 2$ QB 679.

23 Ibid at para 709 .

24 Ibid at para 709. He qualified this: 'I do not say that you would need to find every element in every act which could properly be described as worship, but when you find an act which contains none of those elements it cannot, in my judgment, answer to the description of an act of worship' (ibid). 
worship at all'. ${ }^{25}$ By contrast, for Lord Denning MR the phrase to be defined was 'the combined phrase, "place of meeting for religious worship" as used in the statute of $1855^{\prime} \cdot{ }^{26}$ For Denning, this connoted 'a place of which the principal use is as a place where people come together as a congregation or assembly to do reverence to God'; 'Religious worship means reverence or veneration of God or of a Supreme Being'. The decision in Segerdal did not, therefore, concern the definition of religion as such. The judgments of Buckley LJ and Winn LJ focused on the definition of worship simpliciter, while Lord Denning sought to define the combined phrase 'religious worship'. It is curious, therefore, that this case concerning registration law was heavily relied upon in the second case, which concerned charity law, to provide a definition of religion.

In the second case, Re South Place Ethical Society, Barralet $v A G,{ }^{27}$ the court held that the South Place Ethical Society, a society for the 'study and dissemination of ethical principles and the cultivation of a rational religious sentiment', was not charitable for the advancement of religion. ${ }^{28}$ Echoing Lord Denning in Segerdal, Dillon J distinguished religion from ethics as being 'concerned with man's relations with God' rather than 'with man's relations with man' and held that 'two of the essential attributes of religion are faith and worship; faith in a god and worship of that god'. ${ }^{29}$ Quoting with approval Buckley LJ's definition of worship in Segerdal, Dillon J concluded that the South Place Ethical Society did not have the purpose of advancing religion because there was no 'worship in the sense which worship is an attribute of religion': 'indeed, it is not possible to worship in that way a mere ethical or philosophical ideal' ${ }^{30}$ No explanation was given as to why worship ought to be a definitional aspect of the term 'advancement of religion'.

While Segerdal was concerned with defining the phrase 'place of meeting for religious worship' under registration law, Re South Place Ethical Society was concerned with defining 'advancement of religion' under charity law. Yet the definition for the former was adopted without question for the latter. The requirement for 'faith in a god and worship of that god' came to be understood as the common law definition of religion, except in relation to Buddhism, which was admitted to be an 'exception'. ${ }^{31}$ And this definition was used to exclude any

26 Ibid at para 707. He noted that the Chapel of the Church of Scientology was not a "place of religious worship' because the creed of the Church of Scientology was 'more a philosophy of the existence of man or of life, rather than a religion' and that there was an absence of 'reverence or veneration' and 'considerable stress on the spirit of man' (ibid, emphasis in original).

27 [1980] 1 WLR 1565.

28 It was held otherwise charitable either for the advancement of education or under the fourth head of charity by analogy with decided cases.

29 Ibid at paras $1571-1572$.

30 Ibid at para 1573 .

$31 \quad R v$ Registrar General, ex parte Segerdal [1970] 2 QB 679 at 707; Re South Place Ethical Society, Barralet $v$ $A G 1980] 1$ WLR 1565 at 1573. 
religions where there was no evidence of worship. For instance, in 1999 the Charity Commission held that the Church of Scientology would not be registered as a charity on the basis that the "core practices of Scientology, being auditing and training, do not constitute worship as they do not display the essential characteristic of reverence or veneration for a supreme being. ${ }^{32}$

\section{Developments in human rights and discrimination law}

At the turn of the twenty-first century, a number of new laws were enacted in England and Wales dealing with religious rights. ${ }^{33}$ These statutory provisions defined and understood religion in broader terms. The Human Rights Act 1998 incorporated Article 9 of the European Convention on Human Rights into domestic law, introducing a positive right to freedom of thought, conscience and religion, including the manifestation of religion or belief. ${ }^{34}$ The domestic courts followed the approach of Strasbourg in adopting a broad understanding of religion or belief, regarding it not only as 'one of the most vital elements that go to make up the identity of believers and their conception of life' but also as 'a precious asset for atheists, agnostics, sceptics and the unconcerned'. ${ }^{35}$ Strasbourg institutions considered claims concerning Scientology, ${ }^{36}$ druidism, ${ }^{37}$ pacifism, ${ }^{38}$ communism, ${ }^{39}$ Nazism, ${ }^{40}$ atheism, ${ }^{41}$ pro-life, ${ }^{42}$ Divine Light Zentrum $^{43}$ and the Moon Sect, ${ }^{44}$ as well as 'splinter' groups within larger traditions, ${ }^{45}$ and invariably did so without questioning whether such claims fitted the definition of religion or belief. ${ }^{46}$ They considered the term 'belief' to require a worldview rather than a mere opinion: it was defined in Campbell and Cosans $v$ United Kingdom as denoting 'views that attain a certain level of cogency,

Church of Scientology Application to Charities Commission (17 November 1999): see <http://www. charity-commission.gov.uk/Library/registration/pdfs/cosfulldoc.pdf >, accessed 14 February 2018. See Sandberg, Law and Religion, chapter 10; Sandberg, Religion, Law and Society, chapter 1.

For discussion of the difference between positive and negative religious freedom, see M Hill and R Sandberg, 'Is nothing sacred? Clashing symbols in a secular world', (2007) Public Law 488-506 at 490-491.

Kokkinakis v Greece App no 14307/88 (25 May 1993) at para 31; R v Secretary of State for Education and Employment and others, ex parte Williamson [2005] UKHL 15 at para 24.

$X$ and Church of Scientology $v$ Sweden App no 7805/77 (5 May 1979).

Chappell v United Kingdom App no 10461/83 (30 March 1989).

Arrowsmith v United Kingdom App no 7050/75 (12 October 1978).

Hazar, Hazar and Acikv Turkey App no 16311/90 (11 October 1991).

$X v$ Austria App no 1747/62 (20 June 1963).

Angeleni v Sweden (1988) 10 EHRR 123, (1986) 51 D\&R 41.

Plattform 'Ärzte für das Leben' v Austria App no 10126/82 (21 June 1988).

Omkarananda and the Divine Light Zentrum v Switzerland App no 8188/77 (19 March 1981).

$X v$ Austria App no 8652/79 (15 October 1981).

Eg Serif v Greece App no 38178/97 (14 December 1999) (mufti elected by mosque congregations in opposition to the mufti appointed by the government).

6 Though claimants have been required to prove the genuineness of their belief and the existence of the religion in question: $X v U K$ App no 7215/75 (12 October 1978); Williamson at para 22. 
seriousness, cohesion and importance'. ${ }^{47}$ In $R v$ Secretary of State for Education and Employment and others ex parte Williamson the House of Lords confirmed that this applies to both religious and non-religious beliefs and that 'Freedom of religion protects the subjective belief of an individual'. ${ }^{48}$ It was noted that, where beliefs are manifested, they need to satisfy 'modest' and 'minimum requirements', which are implicitly laid out in Article 9. ${ }^{49}$ However, their Lordships stated that courts should not 'impose an evaluative filter' at the stage of identifying whether there was a belief, 'except in extreme cases'..$^{\circ}$

An example of such an extreme case concerned the hunting ban. In Whaley $v$ Lord Advocate their Lordships rejected the appellant's contention that hunting with hounds constituted a non-religious belief. ${ }^{11}$ For Lord Hope, this belief did not meet the Williamson threshold since, looking at it 'objectively, hunting with hounds is carried on mainly for pleasure and relaxation for those who take part in it'. ${ }^{2}$ This reasoning was problematic, however, not only because the mention of an objective test contradicted the Williamson dicta that freedom of religion protected subjective beliefs, but also because it suggested that a line was to be drawn between beliefs that fell under Article 9 and others that did not. Lord Hope held that the Strasbourg jurisprudence did 'not support the proposition that a person's belief in his right to engage in an activity which he carries on for pleasure or recreation, however fervent or passionate, can be equated with beliefs of the kind that are protected by Article 9 ', since that would make it difficult to 'set any limits on the range of beliefs that would be opened up for protection'. However, neither his Lordship nor any subsequent judgments on Article 9 have articulated where these limits are to be placed.

The case law on religious discrimination has followed the approach of the human rights jurisprudence not only in adopting a wide definition of religion or belief but also in struggling consistently to identify the limits that are to be placed on it. Discrimination on the grounds of religion or belief was originally

47 App nos 7511/76 and 7743/76 (25 February 1982) at para 36. This was in relation to Article 2 of the first protocol to the ECHR. However, this definition has also been applied to Article 9 in Eweida and Others $v$ United Kingdom App nos 48420/10, 36516/10, 57671/10 and 59842/10 (15 January 2013) at para 81.

48 Williamson at para 24.

49 Ibid: 'The belief must be consistent with basic standards of human dignity or integrity'; 'The belief must relate to matters more than merely trivial. It must possess an adequate degree of seriousness and importance'; 'The belief must also be coherent in the sense of being intelligible and capable of being understood'. These were described as 'objective' requirements, but that does not require the belief itself to be assessed objectively but rather that the criterion against which the belief is to be examined is to be assessed objectively. The definition of 'basic standards of human dignity', for instance, is an objective one. It was also stressed that: 'Overall, these threshold requirements should not be set at a level which would deprive minority beliefs of the protection they are intended to have under the Convention.'

$50 \quad$ Ibid at para 58.

51 [2007] UKHL 53.

52 Ibid at para 18. 
prohibited in England and Wales in relation only to employment, under the Employment Equality (Religion or Belief) Regulations 2003, ${ }^{53}$ which defined religion or belief as meaning 'any religion, religious belief, or similar philosophical belief' ${ }^{54}$ Employment Tribunals used the word 'similar' to exclude certain non-religious beliefs such as nationalistic and political beliefs. ${ }^{55}$ However, the Equality Act 2006, which extended religion or belief discrimination to cover the provisions of goods and services, took the opportunity to remove the word 'similar' and to expressly include lack of belief. The current definition, now found in section 10 of the Equality Act 2010, states that 'religion means any religion' and 'belief means any religious or philosophical belief'. ${ }^{5}$

Ironically, a statement by the then government minister, Baroness Scotland, that the new definition should make no difference itself led to a change in approach by Employment Tribunals. Baroness Scotland stated that the removal of the word 'similar' would make no difference because:

the term 'philosophical belief' will take its meaning from the context in which it appears; that is, as part of the legislation relating to discrimination on the grounds of religion or belief. Given that context, philosophical beliefs must always be of a similar nature to religious beliefs. ... It will be for the courts to decide what constitutes a belief ... but case law

53 SI $2003 / 1660$.

54 Employment Equality (Religion or Belief) Regulations 2003, Reg 2(1).

55 Williams v South Central Limited, ET, Case Number: 2306989/2003 (16 June 2004); Baggs v Fudge [2005] ET1400114/2005 (23 March 2005). See R Sandberg, 'Flags, beards and pilgrimages: a review of the early case law on religious discrimination', (2007) 9 Ecc LJ 87-100.

56 Equality Act 2010, s 10. Definitions of religion also exist in the exceptions from discrimination law afforded to religious groups. Under Schedule 19, para 3, of the Equality Act 2010, employers who have an 'ethos based on religion or belief' can discriminate on grounds of religion or belief in relation to employment. Under Schedule 9, para 2, of the Equality Act 2010, 'organised religions' can discriminate on grounds of sex, marriage and sexual orientation in relation to employment. These terms are undefined by the statute but, in $R$ (Amicus MSF Section) v Secretary of State for Trade and Industry [2004] EWHC 860, Richards J held that term 'organised religion' was narrower than 'religious organisation': he gave the example that 'employment as a teacher in a faith school is likely to be "for purposes of a religious organisation" but not "for purposes of an organised religion"' (at para 116). Under Schedule 23, para 2, of the Equality Act 2010, there is a general exception for 'organisations relating to religion or belief' covering discrimination in relation to goods and services. An 'organisation relating to religion or belief' is defined as

an organisation the purpose of which is-

(a) to practise a religion or belief,

(b) to advance a religion or belief,

(c) to teach the practice or principles of a religion or belief,

(d) to enable persons of a religion or belief to receive any benefit, or to engage in any activity, within the framework of that religion or belief, or

(e) to foster or maintain good relations between persons of different religions or beliefs.

See further M Hill, R Sandberg and N Doe, Religion and Law in the United Kingdom (second edition, Alphen aan den Rijn, 2014), pp 154-160; R Sandberg, 'The right to discriminate', (2011) 13 Ecc LJ $157-181$. 
suggests that any philosophical belief must attain a certain level of cogency, seriousness, cohesion and importance, must be worthy of respect in a democratic society and must not be incompatible with human dignity. Therefore an example of a belief that might meet this description is humanism, and examples of something that might not ... would be support of a political party or a belief in the supreme nature of the Jedi Knights. ${ }^{57}$

This summary of the human rights case law requirements has, paradoxically, been used to change the definition. Employment Tribunals have interpreted Baroness Scotland's words as providing a series of tests which apply to determine whether a belief is capable of being protected. The turning point was the decision of the Employment Appeal Tribunal in Grainger PLC v Nicholson, ${ }^{8}$ which concluded that an asserted belief in manmade climate change, together with the alleged resulting moral imperatives arising from it, was capable of constituting a 'philosophical belief' for the purpose of the 2003 Regulations because it met the criteria laid out by the jurisprudence of the European Court of Human Rights which was directly relevant. Employment Judge Burton summarised the meaning of 'philosophical belief' as including five requirements:

(i) The belief must be genuinely held.

(ii) It must be a belief and not ... an opinion or viewpoint based on the present state of information available.

(iii) It must be a belief as to a weighty and substantial aspect of human life and behaviour.

(iv) It must attain a certain level of cogency, seriousness, cohesion and importance.

(v) It must be worthy of respect in a democratic society, be not incompatible with human dignity and not conflict with the fundamental rights of others. ${ }^{59}$

Although these five principles can be found in the case law of the Strasbourg court, they have not been articulated in such a watertight way by the European Court of Human Rights. The application of the Strasbourg definitions is also problematic since, unlike domestic discrimination law, Article 9 does not distinguish between philosophical and non-philosophical beliefs. Following Grainger, the five requirements have taken on an elevated importance. Employment Tribunal chairs have subsequently applied these requirements as if they were a statutory test and have forgotten the warning in Williamson that 
these should be 'minimum' and 'modest' requirements. ${ }^{60}$ They have interpreted the tests in different ways to reach inconsistent and arbitrary decisions. Employment Tribunals have considered the tests to be met in cases concerning beliefs in spiritualism and psychic powers, ${ }^{61}$ anti-fox hunting beliefs, ${ }^{62}$ beliefs in the virtue of public service broadcasting ${ }^{63}$ and humanist beliefs. ${ }^{64}$ In contrast, other Employment Tribunals have concluded that the tests have not been met in cases concerning Marxist/Trotskyite beliefs held by trade union members, ${ }^{65}$ beliefs in conspiracy theories regarding $9 / 11^{66}$ and a belief that belief that a poppy should be worn during the week prior to Remembrance Sunday. ${ }^{67}$ Drawing any points of principle out of this case law is difficult, to say the least. ${ }^{68}$

The confusion is epitomised by the way that it is now unclear as to whether political beliefs are protected under discrimination law. ${ }^{6}$ In Grainger, it was suggested that Baroness Scotland's choice of words referring only to 'support for a political party' as something that might not be protected left open the question of whether 'a belief in a political philosophy or doctrine' might now fall within the definition. ${ }^{70}$ In Kelly $v$ Unison it was suggested that a distinction could be drawn between 'political beliefs which involve the objective of the creation of a legally binding structure by power or government regulating others', which are not protected, and the beliefs that 'are expressed by his own practice but where he has no ambition to impose his scheme on others', which may be protected. ${ }^{71}$ However, this distinction has not found favour with subsequent Employment Tribunal decisions, with Employment Tribunal chairs in several cases ignoring the question of whether the belief might have been 'political' or stating that the appellate courts had not definitely determined the question of whether political beliefs could now be included.

The confusion here results from the partial harmonisation of the definition of religion or belief in human rights and discrimination law contexts. Employment Tribunals have followed Baroness Scotland in adopting the wide approach to the definition of belief found in human rights law but they have come unstuck given

60 Williamson at para 24 .

61 Greater Manchester Police Authority v Power [2009] EAT 0434/09/DA (12 November 2009).

62 Hashman v Milton Park (Dorset) Ltd [2011] ET 3105555/2009 (31 January 2011).

63 Maistryv The BBC [2011] ET 1213142/2010 (14 February 2011). The definition point was not challenged on appeal: [2014] EWCA Civ 1116.

64 Streatfield v London Philharmonic Orchestra Ltd [2012] 2390772/2011(22 May 2012).

65 Kellyv Unison [2009] ET 2203854/08 (22 December 2009).

66 Farrell v South Yorkshire Police Authority [2011] ET 2803805/2010 (24 May 2011).

67 Lisk v Shield Guardian Co Ltd Q Others [2011] ET 3300873/2011 (14 September 2011).

68 See further Sandberg, Religion, Law and Society, pp 38-46; R Sandberg, 'A question of belief' in N Spencer (ed), Religion and Law (London, 2012), pp 51-63.

69 See further R Sandberg, 'Are political beliefs religious now?', (2015) 175 Law and Justice 180-197.

70 Grainger at para 28.

71 Kelly at para 114. This distinction is odd, however, given that many religions proselytise and so could be said to have an ambition to impose their beliefs on others. 
that discrimination law explicitly protects only religious or philosophical beliefs. ${ }^{72}$ As with the adaption of the registration law definition of religion for charity law purposes in Re South Place Ethical Society, the pragmatic appropriation of definitional criteria is problematic, given that significant differences between the definitions have been ignored. The problem is that the move towards a universal definition has been half-hearted.

\section{Developments in charity law}

This problem has increased in the context of charity law itself. The Charities Act 2006 , in providing the first codification of centuries of case law, stated that religion includes 'a religion which involves belief in more than one god, and a religion which does not involve belief in a god'. ${ }^{73}$ This removed theoretical uncertainty surrounding whether the Segerdal-South Place Ethical Society formula excluded those faiths which do not believe in a god, such as Buddhism. The inadequacy of the common law definition had been shown in the judgments themselves, where the judges had accepted that Buddhism was clearly a religion despite being outside the letter of the articulated definition. And so, again like the removal of the word 'similar' in the discrimination law context, the purpose behind the partial definition in the Charities Act was to clarify rather than change the law. However, here too, the revised definition prompted a change in the interpretation of the right. In determining whether an application satisfied the definition of advancement of religion, the Charity Commission came to the conclusion that there were now 'four characteristics of a religion for the purpose of charity law', curiously relying exclusively on its own guidance to modernise the common law test in light of the 2006 Act. ${ }^{74}$ In its decision on an application by the Gnostic Society, ${ }^{75}$ the Charity Commission held that the four characteristics of a religion were:

a. belief in a god (or gods) or goddess (or goddesses), or supreme being, or divine or transcendental being or entity or spiritual principle, which is the object or focus of the religion (referred to ... as 'supreme being or entity');

72 This uncertainty is even more problematic given the changes as a result of the Legal Aid, Sentencing and Punishment of Offenders Act 2012 and a hike in costs. For discussion of the effect of legal aid cuts upon the religious disputes, see R Sandberg and S Thompson, 'The sharia debate: the missing family law context', (2016) 177 Law \& Justice 188-192; R Sandberg and S Thompson, 'Relational autonomy and religious tribunals', (2017) 6 Oxford Journal of Law and Religion 137-161.

73 Section 2(3)(a). This is now to be found in section 3(2)(a) of the Charities Act 2011.

74 Charity Commission, 'Analysis of the law underpinning Public Benefit and the Advancement of Religion' December 2008, <https://www.gov.uk/government/uploads/system/uploads/attachment_data/file/358534/lawrel1208.pdf $>$, accessed 14 February 2018. 'The 2006 Act provided that the Commission could issue guidance, but there is nothing in the Act to suggest that this guidance will be binding. The Commission is subject to the existing law of charities, just as it was before enactment': J Hackney, 'Charities and public benefit', (2008) 124 Law Quarterly Review 347-350 at 350. Application for Registration of the Gnostic Centre (16 December 2009) at para 23. 
b. a relationship between the believer and the supreme being or entity by showing worship of, reverence for or veneration of the supreme being or entity;

c. a degree of cogency, cohesion, seriousness and importance;

d. an identifiable positive, beneficial, moral or ethical framework. ${ }^{76}$

The first two characteristics elaborated and developed the common law definition of religion which required belief in and worship of a god. Although this was presumably intended to reflect the provisions of the Charities Act 2006, the first characteristic is inconsistent with the statute. While belief in multiple gods was mentioned, the statutory language of 'a religion which does not involve belief in a god' is missing. The provision seems to have been interpreted restrictively by the Charity Commission to only include 'spiritual' or 'transcendental' beliefs that did not involve a belief in a god rather than beliefs that denied the existence of God. The language of the Act seemed to include atheism; the language of the Charity Commission excludes atheism and questions whether humanism is protected. The Charity Commission simply introduced synonyms for God, summarised in the phrase 'supreme being or entity'.

The Commission's second characteristic updated the common law test concerning worship. It is notable that parts of the common law definition of worship ('reverence', 'veneration') were now considered to be interchangeable with the term itself. Presumably, the Charity Commission considered itself bound by South Place Ethical Society to include this characteristic, despite the fact that logically there is no reason why worship should be a definitional attribute of 'advancement of religion' under charity law (as opposed to 'a place of meeting for religious worship' under the Places of Worship Registration Act 1855). Although secular belief systems may still enjoy the fiscal and legal benefits of being charitable provided that they come under another head of charity,77 their exclusion from the head of advancement of religion may well infringe Article 9 ECHR, which talks of the right to manifest religion or belief in worship, teaching, practice or observance. ${ }^{78}$

This point is underlined by the third characteristic articulated by the Charity Commission, which brought charity law in line with the requirements found in the Article 9 jurisprudence requiring 'cogency, cohesion, seriousness and importance', again without the Williamson warning that 'too much should not

76 Ibid.

77 In 2002 the Charity Commission recognised the 'promotion of religious harmony' as a new charitable purpose which is not restricted to 'religions' hitherto recognised under charity law but also includes 'beliefs' as recognised by the ECHR. See <https://www.gov.uk/government/publications/promotion-of-religious-harmony $>$, accessed 14 February 2018; also now Charities Act 2011, s 3(1)(h).

78 See further P Edge, 'Charitable status for the advancement of religion: an abolitionist's view', (1995/ 6) 3:1 Charity Law \& Practice Review 29-35. 
be demanded in this regard' and that these are to be interpreted as 'minimum' and 'modest' requirements. ${ }^{79}$ As with discrimination law, aspects of the definition of religion for Article 9 purposes became part of the charity law definition but no attempt was given to square the fact that charity law does not protect 'religion or belief' but only religion (and beliefs in a 'supreme being or entity'). Indeed, both the third and fourth characteristics were new and lacked any statutory or judicial authority. The fourth characteristic introduced a public benefit requirement into the Charity Commission's definition of religion, muddying the Commission's own distinction between identifying whether a trust has met a description of charitable purposes and identifying whether there is a public benefit. $^{80}$

As with the five tests laid out in Grainger, the Charity Commission's four characteristics have led to seemingly arbitrary decisions. The decision in relation to the Gnostic Society relied heavily upon the fourth characteristic and seemingly rejected the application on the basis that the Society did not correspond with the Commission's expectations of an institutional religion. Although the Gnostic Society prayed for humanity and followed Christian teachings such as 'love thy neighbour', the Commission found it striking that 'there was no evidence of consistent application of such codes on their website or in the literature. ${ }^{81}$ The dismissal of the application of the Gnostic Society was followed by the successful application by the Druid Network. ${ }^{82}$ In this decision, the Commission again applied its four characteristics of religion. ${ }^{83}$ Here, however, in relation to the fourth characteristic, the Commission referred to the Network's 'principle of honourable relationships' and the way in which the promotion of ethical codes were integrated explicitly in its objects and through its website. ${ }^{84}$ The Commission therefore concluded that there was 'evidence of an identifiable positive beneficial ethical framework promoted by the Druid Network that is capable of having a beneficial impact on the community at large. ${ }^{85}$ The weight afforded to the presence of doctrinal statements on the Internet is concerning. It is difficult to disagree with the assessment of Luxton and Evans that the reasoning of the Commission in both the Gnostic Society and Druid Network applications was reached 'in reliance on the Commission's own guidance with virtually no mention, let alone analysis, of the underlying case law and

Williamson at para 24 .

Peter Luxton and Nicola Evans have pointed out that the guidance document which the Commission cites 'curiously makes no mention of the fourth characteristic, and so, not surprisingly makes no attempt (at least directly) to provide legal authority for it': P Luxton and N Evans, 'Cogent and cohesive? Two recent charity commission decisions on the advancement of religion', (2011) 75:2 Conveyancer and Property Lawyer 144-151 at 146.

81 Application for Registration of the Gnostic Centre at para 44.

82 Application for Registration of the Druid Network (21 September 2010).

83 Ibid at para 20.

84 Ibid at paras 50 and 51 .

85 Ibidt at para 53 . 
its application to the case in hand' ${ }^{86}$ For Luxton and Evans, these two decisions demonstrated 'the Commission's lack of awareness of the need for legal rigour when making a legal decision'.

The two decisions also show further the problems resulting from the partial appropriation of definitional criteria from the human rights jurisprudence. The four characteristics represented a confused cocktail of criteria adapted from the Commission's own guidance, the human rights jurisprudence, the Charities Act 2006 and the common law definition, which itself appropriated the registration law definition of 'religious worship'. Ironically, although this last criterion was the most legally binding upon the Commission given the South Place Ethical Society judgment, it was also the criterion that felt most out of sync with the other developments, given the wider adoption of the human rights approach. Indeed, the House of Lords in Williamson held that the 'trend of authority (unsurprisingly in an age of increasingly multicultural societies and increasing respect for human rights) is towards a "newer, more expansive, reading" of religion'. ${ }^{87}$ It could therefore have been expected that any new judicial decision on the definition of religion would take the opportunity not only to place the South Place Ethical Society judgment aside but also to further harmonise the definition of religion following the approach taken by both the Charity Commission and Employment Tribunals in terms of bringing the law in line with the human rights jurisprudence. Unfortunately, when the opportunity arose for the judiciary to reconsider the matter in $R$ (on the Application of Hodkin) $v$ Registrar General of Births, Deaths and Marriages, ${ }^{88}$ it was in the context of registration rather than charity law and the Supreme Court did not go as far as it could have done.

\section{THE MOVE AWAY FROM A UNIVERSAL DEFINITION}

\section{The decision in Hodkin}

The decision in Hodkin was on the exact same point as Segerdal, ${ }^{8}$ namely whether a chapel of the Church of Scientology could be registered as 'a place of meeting for religious worship' under the Places of Worship Registration Act 1855 . Given that the lower courts were bound by the previous decision, the case ultimately found itself in front of the Supreme Court. It was unsurprising, given the legal and social changes since 1970, that Lord Toulson in Hodkin noted that 'the understanding of religion in today's society is broad' and overruled the decision in Segerdal. ${ }^{\circ}$ It was surprising, however, that the Supreme Court 
considered arguments based on human rights to be unnecessary, deciding to overrule Segerdal on other grounds, and created a definition that could only apply for the purposes of the Places of Worship Registration Act $1855 .{ }^{91}$

In some respects Lord Toulson's speech pointed towards a universal definition of religion. In contrast to the judgments in Segerdal, Lord Toulson held that the question of whether there was religious worship was 'inevitably conditioned by whether Scientology is to be regarded as a religion'..$^{92}$ Lord Toulson upheld the High Court's decision that Scientology was a religion and stressed that the phrase 'place of meeting for religious worship' found in the 1855 Act had to be interpreted in 'accordance with contemporary understanding of religion and not by reference to the culture of 1855 '. ${ }^{93}$ This meant that, in the absence of 'some compelling contextual reason for holding otherwise, religion should not be confined to religions which recognise a supreme deity', since this would 'be a form of religious discrimination unacceptable in today's society'. ${ }^{94}$ His Lordship held that confining religion in such a way would lead the court 'into difficult theological territory' in a way that was inappropriate. ${ }^{95}$ And he noted that the fact that Lord Denning in Segerdal recognised the need to make an exception for Buddhist temples and the absence of a satisfactory explanation for the rule were 'powerful indications that there is something unsound in the supposed general rule'. ${ }^{96}$ The statutory language instead called for an 'intentionally broad sweep'. ${ }^{97}$

However, in articulating what religion meant, Lord Toulson's speech pointed against a universal definition of religion by providing 'a description and not a definitive formula' of religion which could only serve for the purposes of the 1855 Act. Drawing upon the jurisprudence of other common law jurisdictions, ${ }^{98}$ his Lordship held that religion could be described in summary as:

a spiritual or non-secular belief system, held by a group of adherents, which claims to explain mankind's place in the universe and relationship with the infinite, and to teach its adherents how they are to live their lives in conformity with the spiritual understanding associated with the belief system. ${ }^{99}$

This description is problematic in three respects. First, the reference to 'spiritual or non-secular' creates a distinction between secular and non-secular beliefs 
which is not compatible with Article 9 ECHR, discrimination law and arguably the Charities Act 2011 (though not the Charity Commission's interpretation of it). As Lord Toulson pointed out, the exclusion of secular belief systems is appropriate under the Places of Worship Registration Act 1855 because there are other legal provisions which allow for secular wedding services on approved premises. ${ }^{100}$ Yet this means that Lord Toulson's description cannot and should not be used in other areas of the law where alternative and equal provision is not afforded to secular beliefs. His Lordship's distinction between spiritual and secular is also challenging because it would again seem to open the door to inappropriate theological debates. This is ironically Lord Toulson's reason for omitting any reference to a supreme being. He clarified that he intended to refer to 'a belief system which goes beyond that which can be perceived by the senses or ascertained by the application of science' and preferred not to use the term 'supernatural' to express this 'because it is a loaded word which can carry a variety of connotations'. However, this would seem to overlook the fact that this same criticism would also apply to the word 'non-secular'. ${ }^{101}$ The same criticism can be applied to Lord Toulson's reference to 'the infinite'. It is difficult to see how this is a significant improvement upon talk of a 'supreme being'. It would have been preferable not to state what a belief is to be about but rather to adopt the human rights approach that beliefs are worldviews.

Second, Lord Toulson's definition viewed religion as being necessarily a collective affair; it is something 'held by a group of adherents'. ${ }^{102}$ Again, this is appropriate in the context of the 1855 Act but should not have wider application. Human rights, discrimination and charity law decisions have all protected individuals who develop their own religious beliefs, including in ways that differ from the mainstream of the religious group. ${ }^{103}$ Such beliefs would be excluded by Lord Toulson and so it is questionable whether the description is compliant with Article 9. Third, while Lord Toulson's speech is helpful in that it underlined that the definitions of religion and worship for the purpose of the 1855 Act should be dealt with distinctly, it is regrettable that further clarity on the definition of worship was not provided. Lord Toulson dealt with the question of worship separately but briefly. He held that, even if the meaning given to worship in Segerdal 'was not unduly narrow in 1970, it is unduly narrow

100 Ibid at paras $58-59$.

101 The matter is confused further by the way in which terms such as 'secular', 'secularisation' and 'secularism' are used interchangeably. See, eg, J Casanova, 'The secular, secularizations, secularism' in C Calhoun, M Juergensmeyer and J Van Antwerpen (eds), Rethinking Secularism (Oxford, 2011), 54-74.

102 Hodkin at para 57, emphasis added.

103 This would include, for example, Christians who felt obliged to wear crosses even though the majority do not feel so obligated. The European Court of Human Rights' decision in Eweida suggests that such persons should be protected under Article 9. In the context of charity law, see the decision in Thornton $v$ Howe (1862) 31 Beavan 14. 
now'. ${ }^{104}$ The term 'religious worship' should be interpreted as being 'wide enough to include religious services, whether or not the form of service falls within the narrower definition adopted in Segerdal. ${ }^{105}$ Unfortunately, his Lordship gave no further guidance as to how wide the definition of worship was to be now, only quoting from dictionary definitions which defined worship as including performing acts of adoration, feeling or expressing reverence and adoration, and taking part in religious services, religious rites and ceremonies. $^{106}$

Although it provided some clarity in making a number of general remarks about the need for a broad definition of religion, Lord Toulson's description was deliberately applied solely for the purposes of the Places of Worship Registration Act 1855. There are several elements of the description which could lead to unfortunate results if applied in relation to human rights, discrimination law or even charity law. This is to be regretted since, despite Lord Toulson's insistence that he was providing a description not a definition, the fact that this description was given in a Supreme Court judgment means that it is likely to be very influential in a number of areas of law. This is especially true in relation to charity law, given that the definition of religion in South Place Ethical Society was based upon the Segerdal decision which Hodkin overruled. Unlike in Segerdal, the Supreme Court in Hodkin did not regard 'worship' as part of the definition of 'religion'. It would be expected that this should have implications for the charity law definition of advancement of religion. However, when it fell to the Charity Commission to decide the extent to which Hodkin would affect its fourfold definition of religion, the Commission's decision further muddied the waters. Given the complex ways in which the various case laws concerning the definition of religion have overlapped it was perhaps fitting that the first opportunity for the Charity Commission to determine this came not in relation to the Church of Scientology (which is yet to reapply for charitable status for the advancement of religion) but in relation to one of the examples given by Baroness Scotland of what 'might not constitute a religion or belief': Jediism.

\section{Return of the Jedi}

Despite Baroness Scotland's remark, the question of whether Jediism (a belief 'in the Force' that is linked to ideas found within Star Wars film series)

104 Hodkin at para 61.

105 Ibid at para 62.

106 Indeed, it was curious that, instead of following South Place Ethical Society in regarding worship as a definitional attribute of religion, Lord Toulson identified 'teaching' as part of his description. This raises similar concerns as the old common law definition, given that Article 9 ECHR refers to religion or belief being manifested 'in worship, teaching, practice and observance'. Lord Toulson's definition only seems to relate to teaching and observance. 
constitutes a religion is not as outlandish as it may first appear. ${ }^{107}$ An academic literature exists on so-called 'hyper-real religions', that is, 'how some science fiction, horror, and fantasy narratives can be understood as cultural reservoirs for the construction of religion by spiritual consumers' ${ }^{108}$ And even if a significant number of those who declared their religion as Jediism in recent UK censuses did so as a joke or protest, the fact that the size of those numbers was comparable to other groups such as the Church of Scientology meant that it cannot be completely ignored. ${ }^{109}$ Moreover, regardless of the subject matter of the claim, the Charity Commission's decision to reject an application for registration by the Temple of the Jedi Order (TOTJO) provided the first opportunity to see how Hodkin has affected its understanding of the definition of religion. ${ }^{110}$ The decision noted that the 'definition and characteristics of religion for the purposes of charity law are distilled' from statutes and cases on charity law and their published guidance, which is now 'influenced' by Hodkin although it 'did not relate to a matter of charity law'."1 The influence of Hodkin led the Charity Commission to re-formulate certain aspects of its four characteristics of a religion in ways that were often startling.

The influence of Hodkin was most visible in the reformulated first characteristic that now spoke of a need for a 'Belief in one or more gods or spiritual or non-secular principles or things'. Following Hodkin, the 'faith in a god' test now does not include reference to supreme beings but rather talks of 'principles or things' and distinguishes between spiritual and secular belief systems. This allowed the Charity Commission to continue its narrow interpretation despite the fact that, as it noted, 'the statutory definition of religion includes religions which do not involve belief in a god'. ${ }^{112}$ For the Charity Commission, religions that do not involve belief in a god will only be religions if the principle or thing they believe in is spiritual and non-secular. This follows Hodkin but ignores the fact that the exclusion of secular belief systems made sense in the context of the registration of premises for the solemnisation of marriage because there are other legal provisions which allow for secular wedding services on approved premises. In contrast, there is no argument for making a distinction between secular and non-secular beliefs for the purpose of charity law

107 For an account of Jediism as a religion, see B Singler, 'Internet-based new religious movements and dispute resolution' in R Sandberg (ed), Religion and Legal Pluralism (Aldershot, 2015), pp 161-178.

108 A Possamai, Religion and Popular Culture: a hyper-real testament (Brussels, 2005), p 58. See also

C Cusack, Invented Religions: imagination, fiction and faith (Aldershot, 2010). Other hyper-real religions inspired by science fiction include neo-Pagan groups such as the Church of All Worlds, as well as largely Internet-based movements such as Matrixism (based on The Matrix film trilogy by Larry and Andy Wachowski).

109 The number of Jedis was 390,127 in the 2001 census and 176,632 in the 2011 census.

Scientology's numbers in the UK censuses were 1,781 in 2001 and 2,418 in 2011.

110 Application for Registration by the Temple of the Jedi Order (16 December 2016).

111 Ibid at para 9.

112 Ibid at para 15 . 
(although Charity Commission decisions before Hodkin had distinguished between 'spiritual' or 'transcendental' beliefs and beliefs that denied the existence of a supreme being or entity). It is true that secular beliefs can still be charitable if they fulfil a different charitable purpose such as the promotion of moral or ethical improvement. However, this seems out of sync with the general direction of human rights and equality laws protecting both secular and non-secular worldviews and an argument could be made that the narrow approach taken by the Charity Commission is incompatible with Article 9 ECHR. The influence of Hodkin in removing the synonyms for God is to be welcomed but its influence in distinguishing secular and non-secular belief systems seems to have overshadowed what that judgment also said about the need for a broad approach to definition.

The second requirement seems unaffected by Hodkin other than the removal of the mention of supreme beings. The 'worship of a god' test from Re South Place Ethical Society has been revised so that now there must be a 'Relationship with the gods, principles or things which is expressed by worship, reverence and adoration, veneration, intercession or by some other religious rite or service'. It is questionable whether worship should be a compulsory definitional attribute for the purposes of charity law, especially given that Segerdal (the case upon which Re South Place Ethical Society relied) is no longer good law. It is also noticeable that this section of the Charity Commission's decision on Jediism does not cite Hodkin. The Charity Commission appears to have ignored the fact that the Supreme Court did not regard worship as part of the definition of religion. Even if it is accepted that this test should still apply in charity law, the Hodkin dicta that the Segerdal test was 'unduly narrow' and that the term should be interpreted as being 'wide enough to include religious services' has also been disregarded by the Charity Commission. In contrast, the Commission decided that, despite evidence of meditation, sermons and 'transcripts of the Live Services', Jediism did not meet this second requirement. Curiously, two factors were singled out in this part of the decision: the fact that 'TOTJO is an entirely web based organisation' and 'that Jediism may be adopted as a lifestyle choice as opposed to a religion'. ${ }^{113}$ This seems to be a conservative approach, rejecting the possibility that religious activity can occur online and policing a rigid and artificial line between religion and lifestyle choices which is out of sync with the approach under English law to regard religious groups like any other voluntary associations. ${ }^{114}$

The fact that Hodkin did not rely upon the ECHR case law has not affected the Charity Commission's third characteristic of religion, which is now framed as 'Cogency, cohesion, seriousness and importance in the form of the belief 
system'. The reference to 'belief system' is interesting here given that charity law protects 'religion' rather than 'religion or belief'. This underlines that some forms of belief are to be included as part of the definition of religion. The inclusion of this ECHR requirement is preferable to its exclusion in Hodkin given the requirements of the Human Rights Act 1998. However, again the Williamson warnings about these requirements needing to be set at a 'minimum' and 'modest' level are omitted. ${ }^{115}$

Furthermore, the way in which the Charity Commission articulated this requirement is problematic in two respects. First, the Commission stated that Jediism is not a 'sufficiently cogent and distinct religion'. ${ }^{116}$ No authority is given for this requirement that a religion needs to be 'distinct' and, although ecumenical and interfaith groups could instead seek charitable status for the promotion of religious harmony, ${ }^{117}$ this novel requirement would prove problematic given that many religions have much in common and religions often develop from one another. Second, the Commission stated that there 'is insufficient evidence of an objective understanding of Jediism as opposed to a selfdefining system which may be pursued outside the confines of a religion and in a secular manner' and placed weight on the fact that 'it is not obligatory to interpret and follow the Jedi Doctrine as a religion'. ${ }^{118}$ The Commission considered that: 'Any cogency and cohesion that is present is eroded by the individual's ability to develop themselves within a loose framework and follow an individual experiential philosophy or way of life as a secular belief system." ${ }^{\prime 19}$ This would rule out individualised religious experiences contrary to the principle expressed in Williamson that 'Freedom of religion protects the subjective belief of an individual $^{120}$ and the general approach that individuals can manifest their religion by practices that they do not share with their co-religionists and which are not obligatory according to their faith. ${ }^{121}$

The fourth requirement, that 'Doctrines and practice are of benefit to the public [and are] capable of providing moral and ethical value or edification to the public', remained unchanged and continued the Charity Commission's suspect practice incorporating a public benefit requirement into the Commission's definition of religion.

The Jediism decision clearly represented a development in the Charity Commission's understanding of the definition of religion. It revealed that the Commission has relied upon Hodkin in deeply selective ways that are 
problematic. Without questioning the actual decision, elements of the reasoning by the Charity Commission are cause for concern. In relation to the first requirement, the influence of Hodkin has been significant and has led to the adoption of a distinction between the secular and non-secular that is not appropriate outside the registration context. By contrast, in relation to the second requirement, Hodkin has been ignored and worship remains a definitional attribute of religion for charity law purposes as if Segerdal were still good law. Further, a questionable distinction has been made between religions and lifestyle choices that seems to apply only in relation to charity law. The Charity Commission's articulation of their third characteristic shows that they are not only deriving guidance from the ECHR case law but are embellishing it in ways that are problematic, adding a requirement that religions need to be 'distinct' and operating from an assumption that religions can be objectively described, that they are obligatory upon members and that members are uniform in how they manifest their religion. The Jediism decision underscores how the definition of religion under English law is now hideously confused.

\section{CONCLUSION: THE NEED FOR A UNIVERSAL DEFINITION OF RELIGION?}

In Hodkin, Lord Toulson stated that there were several reasons why there had never been a universal legal definition of religion in English law, namely the different contexts in which the issue may arise and increased religious pluralism and diversity. ${ }^{122}$ These factors, though important, are not fatal to the quest for definition. ${ }^{123}$ Although religious pluralism and diversity renders the definition of religion more difficult, it also renders it more important. The sociological fact that religion 'can no longer be equated with familiar mainstream church and denominational forms but takes a plurality of guides' renders 'the boundaries between religion and non-religion bewilderingly fuzzy'. ${ }^{124}$ It also makes the legal definition of religion increasingly vital. Legal decision-makers rarely have the luxury of a 'fuzzy' outcome and the decisions they make affect not just the claims in front of them but those who will bring and will not bring claims in the future. Defining religion is an exercise in power that has significant legal, political, economic, social and cultural effects. ${ }^{125}$ As James Wiggins has argued, religious diversity requires the conclusion that the definition of religion 'must

122 Hokdin at para 34 .

123 See further Sandberg, Religion, Law and Society, pp 30-38.

124 M Hamilton, The Sociology of Religion: theoretical and comparative perspectives (second edition, Oxford, 2001), p 13 .

125 For an example of how definitions evolve over time within both legal and cultural contexts, see $\mathrm{S}$ Thompson, 'In defence of the "gold-digger", (2016) 6:6 Onati Socio-Legal Series 1225-1248. 
become more expansive and elastic than ever before in human history'. ${ }^{26}$ Yet an overly expansive approach may render the term 'religion' meaningless. The central problem remains that identified by the sociologist Georg Simmel: managing to craft a definition of religion that is both precise and sufficiently comprehensive. ${ }^{127}$

The approach generally taken by English law has been to regard the difficulties surrounding the definition of religion as requiring the crafting of several stipulative or specific definitions of religion developed by the case law on each area of law rather than crafting a lexical or universal definition of religion. Yet this approach has proved to be inadequate. From South Place Ethical Society onwards, there has been a tradition of pragmatically appropriating parts of definitions of religion from one legal context into another. The incorporation of Article 9 into domestic law and the requirement to read legislation where possible in a Convention-compliant way has given legal force to this harmonisation. However, in recent years legal decision-makers have swum against this tide and in so doing have created waves that may well torpedo future claims. In Hodkin, Lord Toulson noted the need for a broad definition of religion but only provided a description of religion for the purpose of the 1855 Act. The limitations of this came to the fore in the Charity Commission's decision on Jediism, which underscored how confused and arbitrary the case law has become. There Hodkin was relied upon to erect a problematic distinction between secular and non-secular belief systems that now applies under charity and registration law but not under human rights and discrimination law. Hodkin was then ignored, to state that worship remains a definitional attribute of religion for charity law purposes, despite the fact that the Segerdal decision upon which South Place Ethical Society relied is no longer good law.

Unlike in Hodkin, the Charity Commission applied ECHR standards about the nature of a religion or belief. This followed the trend set by Employment Tribunals whereby those standards apply in discrimination law despite that area of law protecting only religious and philosophical beliefs (rather than beliefs per se), and these standards have been interpreted in a more demanding way outside the context of human rights law. ${ }^{128}$ The level of uncertainty, the arbitrary distinctions drawn and the questionable interpretation of the new tests created by the Charity Commission and Employment Tribunals are matters of concern not only in terms of whether the reasoning is compatible with Article

126 J Wiggins, 'What on earth is religion?' in T Idinopulos and B Wilson (eds), What is Religion? Origins, definitions Q explanations (Leiden, 1998), pp 133-139.

127 G Simmel, 'A contribution to the sociology of religion', reprinted in G Simmel, Essays on Religion (New Haven, CT, 1997), pp 101-120.

128 The decisions of the Charity Commission show that these standards also apply in charity law despite that area of law protecting only religious beliefs, which have been understood to possibly include non-secular beliefs. 
9. A number of statements made by courts and tribunals are troubling on closer inspection and constitute the 'stuff of theological debate' which Lord Toulson was keen to avoid as a matter of principle. ${ }^{129}$ The time is therefore apt to reconsider a universal definition of religion under English law.

The case law reveals that elements of a universal definition already exist. These need to be refashioned in order to remove inconsistencies that exist in different areas of law. The Charity Commission in its recent decisions has spoken of there being four characteristics. Re-examining these in turn, taking into account developments in registration, human rights and discrimination law, may point to a way forward, drawing upon insights from the sociology of religion. ${ }^{130}$

The first characteristic is that there is a belief. While registration and charity law decisions (and legislation) have sought to define what the belief is about (by talking about supreme beings or lack of such beings and, from Hodkin onwards, distinguishing between secular and non-secular beliefs), human rights law has focused on what beliefs do (by looking for a worldview and ruling out mere opinions, or beliefs that are not genuinely held). Discrimination law has adopted a halfway approach, generally following the human rights case law but specifying that beliefs must be religious or philosophical and may or may not be political. The differences here are reminiscent of a distinction often drawn by sociologists of religion between substantive definitions which identify religion for what it is and functional definitions which identify religion for what it does. ${ }^{131}$ While registration and charity law have generally adopted a substantive definition of religion, human rights and discrimination law have adopted a functional approach. There are elements of a functional definition of religion in Lord Toulson's description in Hodkin where the language of supreme beings is dropped and it is stated that a religion is held by a group of adherents and that it 'claims to explain mankind's place in the universe and relationship with the infinite' and to teach each others how to live their lives. ${ }^{132}$ However, this assumes that religious activity is collective and also ignores the other ways in which religion can be manifested (by worship, practice and observance,

129 Hodkin at para 52.

130 For discussion of how the sociological and legal study of religion should interact, see Sandberg, Religion, Law and Society.

131 Examples of substantive definitions in sociology include Edward Burnett Tylor's 'minimum definition' of religion as 'the belief in Spiritual Beings' (E Tylor, Primitive Culture (2 vols, London, 1920), vol I, p 424) and Steve Bruce's list that religion 'consists of beliefs, actions and institutions which assume the existence of supernatural entities' (S Bruce, Religion in Modern Britain (Oxford, 1995), p ix). The most famous functional definition in sociology is that provided by Durkheim, who defines religion as 'a unified set of beliefs and practices'; for Durkheim religion is 'something eminently collective', it links people together in communities providing 'social solidarity' (E Durkheim, The Elementary Forms of Religious Life (Oxford, 2001), p 46.)

132 Hodkin at para 57. 
as well as by teaching, according to the letter of Article 9). ${ }^{133}$ However, this could be fashioned into a definition that protects both individual and collective religious freedom. One of the Grainger tests, requiring a belief to be on 'a weighty and substantial aspect of human life and behaviour', appears to go in the right direction. ${ }^{134}$

A functional definition is to be preferred for the very reason that Lord Toulson gave for why a universal definition should not be adopted. His Lordship's reference to 'the different contexts in which the issue may arise' raises the issue of why law protects (or at least facilitates) religion. Post-Toleration, the rationale is no longer the promotion and enforcement of religious uniformity. Rather, law regulates religion as part of human behaviour. Sociologists of religion often refer to their approach towards studying religion as being one of 'methodological agnosticism'. ${ }^{135}$ In the words of Georg Simmel, methodological agnosticism requires a distinction to be drawn between the 'metaphysical event that is readily capable of implying or forming the basis of religion' and 'the subjective attitude of human beings' ${ }^{136}$ Methodological agnosticism requires the making of that distinction and the bracketing aside of the question of the status of religious claims. ${ }^{137}$ As Berger has put it, 'religion is to be understood as a human projection, grounded in the specific infrastructures of human history'. ${ }^{138}$ Methodological agnosticism, as a principle, could inform the interest in definitions taken by lawyers as well as sociologists. ${ }^{139}$ As Roger Cotterrell has noted, 'both law and sociology must define and conceptualize very elusive aspects of human behaviour'. ${ }^{140}$ Sociologists and lawyers are primarily interested in religion as a human activity and take an ultimately 'pragmatical, contextualised approach' to defining religion. ${ }^{141}$ Law does not seek to describe religion as a phenomenon but simply seeks to establish rules to regulate and facilitate its exercise within wider social life.

133 A clearer functional definition can be found in the definition of 'an organisation relating to religion or belief' provided by Schedule 32, para 2, of the Equality Act 2010, which states that this is 'an organisation the purpose of which is 'to practice, advance and teach the principles of that religion, to enable persons of the religion to receive benefits and engage in activities and to improve relations between religious groups'. This, too, assumes that religious activity is collective (given that it is defining an organisation for the purpose of creating exceptions from discrimination law).

134 Grainger at para 24.

135 Sandberg, Religion, Law and Society, p 35.

136 G Simmel, 'Contributions to the epistemology of religion', reprinted in Simmel, Essays on Religion, pp 121-133.

137 M Hamilton, The Sociology of Religion: theoretical and comparative perspectives (second edition, Oxford, 2001), p 5.

138 P Berger, The Sacred Canopy (New York, 1969), p 180.

139 Sandberg, Religion, Law and Society, p 36.

140 R Cotterrell, Law, Culture and Society: legal ideas in the mirror of social theory (Aldershot, 2006), p 2.

141 A Molendijk, 'In defence of pragmatism' in J Platvoet and A Molendijk (eds), The Pragmatics of Defining Religion: contexts, concepts \& contests (Leiden, 1999), pp 3-19 at p 4. 
It follows that a functional approach to defining religion should be taken. The approach of Williamson should be followed; it should generally be accepted that freedom of religion protects the subjective beliefs of the individual, and arbitrary distinctions should not be drawn. There should be no requirement that beliefs must be religious or philosophical (as in discrimination law) or spiritual and non-secular (as in Hodkin and the Jediism decision) or that non-philosophical or political beliefs (as in discrimination law), lifestyles and activities performed for recreation can be clearly distinguished from manifestations of religion or belief (as in Whaley and the Jediism decision). Instead, the word 'religion' should be interpreted as including all forms of belief, including beliefs defined by a lack of belief. There will, of course, be some claims that legal decision-makers will need to exclude but the reason for the exclusion will relate to the human behaviour - the manifestation of the belief - rather than the nature of the belief itself. These claims will typically be excluded not on grounds of the definition of religion but in relation to other tests that need to be satisfied in order for the religious right to be enjoyed. In the context of charity law, the focus will be on the public benefit test; in human rights law, the emphasis will be on the Article 9(2) limitations on the manifestation of religion; and in discrimination law, the importance will be based on proportionality. A functional definition will not protect religious practices that are beyond the pale but such practices will be excluded as manifestations of human behaviour rather than on grounds of the nature of the belief. An approach based on methodological agnosticism would allow legal decision-makers to avoid making difficult and inappropriate theological interpretations.

The second characteristic of religion as articulated by the Charity Commission - worship - should no longer be a definitional attribute. The appropriation of the definition of 'religious worship' from Segerdal by South Place Ethical Society in the attempt to define 'advancement of religion' was questionable at the time and is even more questionable now, given that Hodkin has overruled Segerdal. Lord Toulson's opinion makes it clear that in defining the term 'a place of meeting for religious worship' separate consideration is to be given to the definitions of religion and of worship. It follows that in every other context the definition of worship should not form part of the definition of religion. Rather, it should be accepted that religion can be manifested through worship, teaching, practice and observance (as the text of Article 9 makes plain) and, as Williamson reminds us, the standard here should not be too rigid. A purported religion that carried out acts of cannibalism or terrorism would be denied legal protection not because the nature of such activities did not constitute worship but because of the social harm that they cause. A functional approach based on methodological agnosticism would retain the third characteristic of a religion, requiring a certain level of cogency, seriousness, cohesion and importance, but would follow Williamson in assessing this subjectively, stressing that these requirements are 
understood to be set at a 'modest' and 'minimum' level and by not creating conservative thresholds requiring institutional presences or for each religion to be distinct. The Charity Commission's fourth requirement, that of public benefit, is especially important from a functional methodological agnostic perspective but should not form part of the definition of religion as such, unless perhaps it needs to be stated that religious activities that cause social harm are not to be legally protected. The final limb of the Grainger test may be useful here, as may the guidance in Williamson that a belief must be consistent with basic standards of human dignity or integrity. ${ }^{142}$ In short, adopting a functional methodological agnostic approach to defining religion could lead to the following universal definition under English law:

Freedom of religion protects the subjective belief of an individual. Religion includes all forms of belief, including lack of belief. The belief must be a genuinely held worldview that relates to a weighty and substantial aspect of life and attains a minimum and modest level of cogency, seriousness, cohesion and importance. The belief can be manifested or advanced through worship, teaching, practice or observance. It must be consistent with basic standards of human dignity or integrity. 